\title{
Liraglutide inhibits the progression of prediabetes in rats by reducing Raf-1 kinase inhibitor protein
}

\author{
Fei Gao ${ }^{1 \#}$, Dingying $\mathrm{Wu}^{1 \#}$, Lingling Guo ${ }^{1}$, Lixue $\mathrm{Wang}^{1}, \mathrm{Min} \mathrm{Hao}^{1}$, Ling $\mathrm{Li}^{1}$, Dongmei $\mathrm{Ni}^{1}$, Haojie $\mathrm{Hao}^{2}$ \\ ${ }^{1}$ Department of Endocrinology, Electric Power Teaching Hospital, Capital Medical University, Beijing, China; ${ }^{2}$ Beijing Hengfeng Mingcheng \\ Biotechnology Co., Ltd., Beijing, China \\ Contributions: (I) Conception and design: F Gao, H Hao; (II) Administrative support: D Wu; (III) Provision of study materials or patients: L Guo; \\ (IV) Collection and assembly of data: L Wang, M Hao, L Li; (V) Data analysis and interpretation: F Gao, D Ni, H Hao; (VI) Manuscript writing: All \\ authors; (VII) Final approval of manuscript: All authors. \\ \#These authors contributed equally to this work. \\ Correspondence to: Haojie Hao. Beijing Hengfeng Mingcheng Biotechnology Co., Ltd., Beijing 102206, China. Email: gaofokok@163.com.
}

Background: The cleavage product of Raf-1 kinase inhibitor protein (RKIP), hippocampal cholinergic neurostimulating peptide (HCNP) is involved in the promotion of insulin secretion. Studies have shown that liraglutide can inhibit the progression of prediabetes. This study aims to investigate whether the above effects of liraglutide are related to RKIP and HCNP.

Methods: Insulin-1 (INS-1) cells were divided into control group (CON), HCNP group, and HCNP + darifenacin group (H-DAR). The three groups were cultured with Roswell Park Memorial Institute (RPMI) 1640, synthetic HCNP (50 pg/mL) and RPMI 1640, and HCNP + RPMI 1640 + darifenacin respectively. Subsequently, twelve 12- to 14-week-old Otsuka Long-Evans Tokushima Fatty (OLETF) rats were randomly divided into 2 groups: the placebo group (PBO) and the liraglutide treatment group (LIRA). Six Long Evans Tokushima Otsuka (LETO) rats were used as the control group (CON). The LIRA group was given liraglutide $200 \mu \mathrm{g} / \mathrm{kg}$ intraperitoneally twice a day. After 12 weeks, body weight, fasting blood glucose, 2 hours postprandial blood glucose, and insulin resistance index were recorded. Western blot was used to detect expression level of C-RKIP, N-RKIP, and extracellular signal-regulated kinase of phosphorylation (p-ERK). Real-time quantitative polymerase chain reaction (qRT-PCR) to detect pancreatic tissue choline acetyltransferase (ChAT) and M3 cholinergic receptor (M3R) gene expression levels.

Results: At glucose concentrations of 5.6 and $16.7 \mathrm{mmol} / \mathrm{L}$, the insulin content in the HCNP group was higher than that in the CON and H-DAR groups (all $\mathrm{P}<0.01$ ). The body weight and fasting serum insulin (FINS) of rats in the PBO group were higher than those in the LIRA group and the CON group $(\mathrm{P}<0.01)$. The relative content of C-RKIP protein in the PBO group was higher than that in the LIRA and CON groups $(\mathrm{P}<0.01)$. The relative content of $\mathrm{N}$-RKIP protein and $\mathrm{p}-\mathrm{ERK}$ protein was lower than the LIRA and CON group $(\mathrm{P}<0.05$ and $\mathrm{P}<0.01$, respectively). $C h A T$ and $M 3 R$ gene expression levels in $\mathrm{PBO}$ group were lower than those in LIRA and CON group $(\mathrm{P}<0.01)$.

Conclusions: Liraglutide promotes the production of HCNP, can increase ChAT activity, activate M3R, and further promote the secretion of insulin.

Keywords: Raf-1 kinase inhibitor protein (RKIP); hippocampal cholinergic neurostimulating peptide (HCNP); liraglutide; extracellular regulatory protein kinase; muscarinic cholinergic receptor type 3

Submitted May 12, 2021. Accepted for publication Jul 14, 2021.

doi: 10.21037/atm-21-3094

View this article at: https://dx.doi.org/10.21037/atm-21-3094 


\section{Introduction}

Prediabetes is a state of glucose metabolism disorder between normal blood sugar and diabetes. Its pathogenesis is associated with the damage of pancreatic $\beta$-cells and insulin resistance (1). A number of studies have confirmed that prediabetes is associated with an increased risk of diabetes, cardiovascular disease, and stroke, as well as a significantly increased mortality rate. Thus, prediabetes intervention is of critical importance (2-4). Liraglutide, a human glucagon-like polypeptide analog, plays a role in promoting insulin secretion and promoting $\beta$-cell proliferation. Previous study demonstrated that liraglutide therapy can lead to a significant reduction in visceral adipose tissue and a significant improvement in $\beta$-index (5). Although studies have shown that liraglutide can inhibit the progression of prediabetes, further research is needed to elucidate the precise mechanism by which this occurs $(5,6)$. The extracellular regulated protein kinases (ERK1/2) signal transduction pathway plays an important role in the proliferation of pancreatic $\beta$-cells and insulin secretion(7). As a specific inhibitor of ERK1/2 signal transduction pathway, Raf-1 kinase inhibitor protein (RKIP) can inhibit raf-1 kinase phosphorylation, further inhibit ERK1/2 signal transduction pathway, and reduce cell proliferation (8); studies have shown that RKIP acts specifically in pancreatic islet $\beta$-cells to inhibit $\beta$ cell proliferation (9). The amino terminal of RKIP can be cleaved by sulfhydryl-containing chymotrypsin into a polypeptide of 11 amino acid residues, namely hippocampal cholinergic neurostimulating peptide (HCNP). HCNP can activate choline acetyltransferase in the central nervous system, promote the synthesis of acetylcholine, and then act on the cholinergic neuroreceptor system (10). In vitro experiments have shown that HCNP promotes insulin secretion, but it is not clear whether this effect passes through the cholinergic nervous system. This study's aim was to use in vitro and in vivo experiments to observe whether the inhibitory effect of liraglutide on prediabetes is related to RKIP and its cleavage product HCNP. We present the following article in accordance with the ARRIVE reporting checklist (available at https://dx.doi. org/10.21037/atm-21-3094).

\section{Methods}

\section{Insulin-1 cell culture}

\section{HCNP synthesis and purity detection}

Solid-phase chemical synthesis technology was used to artificially synthesize a peptide containing 11 amino acid residues. The sequence is: H-Ala-Ala-Asp-Ile-Ser-GlnTrp-Ala-Gly-Pro-Leu-OH. Reverse high-performance liquid chromatography (Model 1100 High Performance Liquid Chromatograph, Agilent Company, Palo Alto, CA, USA) and electrospray mass spectrometry (Esquire2LC ion trap electrospray mass spectrometer, Bruker Daltonics Company, Billerica, MA, USA) were used to analyze the products. After separation and purification, the purity of the final product obtained was $98.23 \%$.

\section{Insulin release experiment}

Rat Insulin-1 (INS-1) cells (pancreatic $\beta$-cell tumor cell line) were obtained from the Endocrine and Metabolic Disease Laboratory of Zhujiang Hospital, Southern Medical University. The cells were cultivated in a $75 \mathrm{~mL}$ culture flask, and the growth was observed using an inverted phasecontrast microscope. When $80 \%$ of the cells were fused into a slice, $0.1 \%$ trypsin and $0.1 \%$ EDTA-mixed digestion solution was used to digest and separate the cells. The cells were then seeded in a 6 -well plate with $6 \times 10^{5}$ cells per well. The cells were randomly divided into 3 groups: the control group, the HCNP group, and the HCNP + darifenacin group (H-DAR) group. INS-1 cells in the control group were cultured with RPMI 1640 solution; INS-1 cells in HCNP group were cultured with synthetic HCNP 50 pg/mL (Shanghai Yingjun Biotechnology Co., Ltd., Shanghai, China) and RPMI 1640 solution; and INS1 cells in H-DAR group were cultured with $50 \mathrm{pg} / \mathrm{mL}$ of HCNP, RPMI 1640 solution, and $10 \mu \mathrm{mol} / \mathrm{L}$ of darifenacin (DAR, an M3 choline receptor antagonist; Beijing Biolab Technology Co., Ltd., Beijing, China) 1 hour prior to the insulin secretion experiment. The INS-1 cells of each group were cultured in a $5 \% \mathrm{CO}_{2}$ incubator for 5 days, after which time the supernatant was discarded. A KrebsRinger bicarbonate-HEPES (KRBH) solution containing $3.3 \mathrm{mmol} / \mathrm{L}$ glucose $(115 \mathrm{mmol} / \mathrm{L} \mathrm{NaCl}, 4.7 \mathrm{mmol} / \mathrm{L} \mathrm{KCl}$, $1.28 \mathrm{mmol} / \mathrm{L} \mathrm{CaCl}_{2}, 1.2 \mathrm{mmol} / \mathrm{L} \mathrm{KH}_{2} \mathrm{PO}_{4}, 1.2 \mathrm{mmol} / \mathrm{L}$ $\mathrm{MgSO}_{4}, 10 \mathrm{mmol} / \mathrm{L} \mathrm{NaHCHO}_{3}, 0.1 \%$ bovine serum albumin, $\mathrm{pH}$ 7.4) was used to incubate the cells for 40 minutes. The supernatant was then extracted and the insulin concentration was determined. After washing with $3.0 \mathrm{~mL}$ of $\mathrm{KRBH}$ solution again, $\mathrm{KRBH}$ solution containing 5.6 and $16.7 \mathrm{mmol} / \mathrm{L}$ of glucose was added to each group. The 3 groups were incubated for 40 minutes, after which time the supernatant was collected and the insulin content was determined using radioimmunoassay (Rat Insulin Test Kit, Science and Technology Development Center, PLA 
General Hospital Radio Immune Institute, Beijing, China). All 3 groups were treated with double tubes, and the average value was taken. The insulin release experiment was repeated 3 times.

\section{Grouping and experiment}

\section{Feeding and intervention of rats}

Experimental animals were gifted by the Tokushima Research Institute of Otsuka Pharmaceutical Co., Ltd. Otsuka Long-Evans Tokushima Fatty (OLETF) rats are cholecystokinin-A receptor gene knockout mice, which are characterized by a large food intake, rapid weight gain, hyperinsulinemia, and elevated blood sugar. Type 2 diabetes can occur spontaneously in these rats. Long Evans Tokushima Otsuka (LETO) rats belong to the same strain as OLETF rats but are not cholecystokinin-A receptor gene knockout mice and were thus used as a control group. All rats were male, 4 weeks old, and were fed with common feed in the clean-grade breeding room of the Laboratory Animal Center of Southern Medical University. The room temperature was kept at $21 \pm 2{ }^{\circ} \mathrm{C}$, the light availability was 14 hours, and the humidity was $60 \% \pm 15 \%$. After 8-10 weeks of feeding, all animals were fasted for 15 hours, and oral glucose tolerance test (OGTT with glucose $2 \mathrm{~g} / \mathrm{kg}$ through gastric tube infusion) was performed to detect the blood glucose and diabetes in the tail vein of rats by the glucose oxidase method at 30, 60, 90, and 120 minutes after OGTT. The diagnostic criteria were in accordance with the international rat diabetes criteria (peak blood glucose $>16.8 \mathrm{mmol} / \mathrm{L}$ and blood glucose 2 hours after a meal $>11.1 \mathrm{mmol} / \mathrm{L})$. Impaired glucose tolerance (IGT) was considered when one of these criteria were met. The OGTT experiment was performed again at 2, 4, 6, 8, 10 , and 12 weeks after drug administration to measure the body weight of rats in each group, and the enzymelinked immunosorbent method was used to detect fasting serum insulin (FINS). A random number table was used to randomize 12 OLETF rats in the IGT stag into 2 groups of 6 ; depending on the allocation, the rats were given $200 \mu \mathrm{g} / \mathrm{kg}$ liraglutide (LIRA group, $\mathrm{n}=6$ ) or normal saline $1.0 \mathrm{~mL} / \mathrm{kg}$ (PBO group, $\mathrm{n}=6$ ) twice a day via intraperitoneal injection. The LETO group (CON group, $n=6$ ) rats were given intraperitoneal injection of normal saline. The OGTT experiment was performed every 2 weeks. After 12 weeks, intraperitoneal anesthesia was conducted using $50 \%$ pentobarbital sodium. The pancreas tail tissue was extracted, some tissues were fixed with formaldehyde for immunohistochemical staining, and some were stored at $-80{ }^{\circ} \mathrm{C}$ for western blotting and real-time quantitative polymerase chain reaction (RT-PCR). The sample size of animal experiments was determined according to a previous study (11). During the experiment, only the experiment operator knew the group allocation and treatment allocation of the rats, and the blind was revealed after the experiment was complete and data were being processed. Experiments were performed under a project license (No.: 2017-11-15) granted by ethics committee of Electric Power Teaching Hospital, in compliance with national guideline for the care and use of animals. A protocol was prepared before the study without registration.

\section{Detection}

\section{Immunobistochemical staining}

The specimens fixed with $10 \%$ formaldehyde were embedded in paraffin within 24 hours, dehydrated by alcohol gradient, and subjected to insulin immunohistochemical staining. The morphology of pancreatic islet $\beta$-cells was observed under light microscope, and the insulin positive cell density (PCD) was analyzed by Image J software.

\section{Fluorescence quantitative analysis of pancreatic ChAT and $M 3 R$ genes}

The pancreatic tissue was lysed with Trizol solution, and the total RNA was extracted according to the instructions, and stored at $-80{ }^{\circ} \mathrm{C}$. ChAT messenger RNA (mRNA) and M3R mRNA sequences were analyzed to design specific primers: ChAT upstream primer sequence: 5' -TTCCAAGACACCAATGACCA-3' downstream primer sequence: 5'-AGTGGCTGTCCAGCAGAGTT-3', amplified fragment length 85 bp ; M3R upstream primer 5 '-CATCATTGGCAACATCCTTG-3' downstream primer sequence: 5'-AGGCCAGGCTTAAGAGGAAG-3', and amplified fragment length 89 bp (primers were synthesized by Shanghai Shenggong Biological Engineering Technology Service Co., Ltd.). The ABI 7500 Real-time PCR System (Thermo Fisher Scientific, USA) and SYBR Green RNA amplification kit (Takara Bio Group, Japan) were used to carry out the RT-PCR reaction in a onestep method. The reaction was based on the following kit operation protocols: quantitative RT-PCR system $(20 \mu \mathrm{L})$ : real-time fluorescent quantitative reagent $(2 \times \mathrm{SYBR}$ Premix Ex TaTM) $10 \mu \mathrm{L}$, (ROX Reference Dye II) $0.4 \mu \mathrm{L}$, $10 \mu \mathrm{mol} / \mu \mathrm{L}$ upstream and downstream primers each $0.4 \mu \mathrm{L}$, complement DNA (cDNA) template $1.0 \mu \mathrm{L}$, and double distilled water $17.8 \mu \mathrm{L}$. The reaction conditions were as follows: $94{ }^{\circ} \mathrm{C}$ prereaction for 5 minutes, $94{ }^{\circ} \mathrm{C}$ for 
Table 1 Insulin content of 2 groups of INS-1 cells stimulated by different concentrations of glucose (mean $\pm \mathrm{SD}$ )

\begin{tabular}{lcccc}
\hline Groups & $\mathrm{n}$ & $3.3 \mathrm{mmol} / \mathrm{L}$ & $5.6 \mathrm{mmol} / \mathrm{L}$ & $16.7 \mathrm{mmol} / \mathrm{L}$ \\
\hline HCNP & 12 & $8.38 \pm 0.96$ & $10.26 \pm 1.25^{\star \# \#}$ & $12.77 \pm 1.32^{\star \star \# \#}$ \\
CON & 12 & $8.05 \pm 0.79$ & $9.35 \pm 1.04^{\#}$ & $9.73 \pm 1.14^{\#}$ \\
H-DAR & 12 & $8.16 \pm 1.17$ & $8.30 \pm 0.94$ & $8.52 \pm 1.26$ \\
\hline
\end{tabular}

Compared with CON group, ${ }^{\star \star} \mathrm{P}<0.01$; compared with CON group, ${ }^{*} \mathrm{P}<0.05$; compared with the H-DAR group, ${ }^{\# \#} \mathrm{P}<0.01$; compared with the H-DAR group, ${ }^{*} \mathrm{P}<0.05$. HCNP, hippocampal cholinergic neurostimulating peptide; CON, control group; H-DAR, HCNP + darifenacin group.

30 seconds, $60{ }^{\circ} \mathrm{C}$ for 30 seconds, and $72{ }^{\circ} \mathrm{C}$ for 30 seconds for 40 cycles with fluorescence signals being collected at the end of each cycle of the extension reaction.

\section{Pancreas C-RKIP, N-RKIP, and ERK1/2 protein expression analysis}

The following enhanced chemiluminescence method was used to display protein bands: images were captured with Universal hood II gel imaging system (Bio-Rad, USA); Image $\mathrm{J}$ software was used to analyze the gray value of the band; and $\beta$-actin was used as an internal reference. The primary antibody was purchased from Santa Cruz Biotechnology (Santa Cruz, CA USA); the horseradish peroxidase-labeled secondary antibody, enhanced chemiluminescence kit, and nitrocellulose membrane were purchased from SigmaAldrich (St. Louis, MI, USA); and the standard protein was purchased from Bio-Rad. C-RKIP represents the carboxyterminal RKIP, that is, the complete RKIP protein; N-RKIP represents the amino-terminal RKIP, which indirectly represents the small molecule peptide, HCNP (containing 11 amino acid residues produced by enzymatic cleavage of the amino terminal of the intact RKIP). HCNP is too small to be identified by western blotting, and can only be expressed indirectly by N-RKIP.

\section{Data processing and statistical analysis}

All data were processed and analyzed using SPSS 19.0 software (IBM Corp, Armonk, NY, USA), and normality and homogeneity of variance were tested for the measured results. Continuous data are expressed as mean \pm standard deviation, and comparison between groups was conducted using one-way analysis test. A $\mathrm{P}$ value $<0.05$ was considered significant.

\section{Results \\ INS-1 cell insulin release experiment}

Radioimmunoassay was used to determine the effect of HCNP on insulin release stimulated by different concentrations of glucose. The results showed that when the glucose concentration was $3.3 \mathrm{mmol} / \mathrm{L}$, the insulin content of the cell culture supernatant, the HCNP group, the CON group, and the H-DAR group were not statistically different $(\mathrm{P}>0.05)$. When the glucose concentration was 5.6 or $16.7 \mathrm{mmol} / \mathrm{L}$, the insulin content in the HCNP group was higher than that in the CON and H-DAR groups, and the difference was statistically significant $(\mathrm{P}<0.05$, Table 1$)$.

\section{Pancreatic tissue of prediabetic rats}

\section{Rat body weight, glucose tolerance test and fasting insulin}

After 12 weeks of drug treatment, the body weight, blood glucose and FINS of rats in the PBO group were significantly higher than those in the LIRA and CON groups, and the difference was statistically significant $(\mathrm{P}<0.05$, Table 2).

\section{Pancreatic islets immunohistochemical morphological analysis}

The CON group was observed under a light microscope with regular pancreatic islets morphology, complete structure, and even distribution of PCD in the samples; PCD in the PBO group was significantly reduced and unevenly distributed; the morphology of the LIRA islets was significantly improved. The PCD in the pancreatic islets in LIRA group increased significantly compared with the PBO group (Figure 1, Table 2).

\section{The expression of RKIP and p-ERK protein in rat pancreatic tissue}

Compared with the $\mathrm{PBO}$ group, the relative content of C-RKIP protein in the LIRA and CON groups was significantly reduced, and the relative content of N-RKIP protein was significantly increased $(\mathrm{P}<0.05)$. Compared with 
Table 2 Body weight, blood glucose, insulin resistance index, and insulin-positive cell density of the 3 groups of rats (mean \pm SD)

\begin{tabular}{lcccccc}
\hline Groups & $\mathrm{n}$ & Weight $(\mathrm{G})$ & FBG $(\mathrm{mmol} / \mathrm{L})$ & $2 \mathrm{hPG}(\mathrm{mmol} / \mathrm{L})$ & FINS $(\mathrm{mU} / \mathrm{L})$ & PCD $\left(\mu \mathrm{m}^{-2}\right)$ \\
\hline CON & 6 & $408.75 \pm 18.96^{\#}$ & $6.16 \pm 0.38^{\star \star \#}$ & $7.45 \pm 0.48^{\star \star \# \#}$ & $15.08 \pm 4.54^{\star \star \#}$ & $0.90 \pm 0.12^{\star \star}$ \\
LIRA & 6 & $462.68 \pm 26.54^{\star}$ & $7.34 \pm 0.63^{\star \star}$ & $9.72 \pm 0.52^{\star \star}$ & $18.60 \pm 5.16^{\star \star}$ & $0.78 \pm 0.15^{\star \star}$ \\
PBO & 6 & $516.96 \pm 19.63$ & $8.65 \pm 0.47$ & $12.12 \pm 0.71$ & $25.67 \pm 7.23$ & $0.59 \pm 0.08$ \\
\hline
\end{tabular}

Compared with PBO group, ${ }^{* \star} \mathrm{P}<0.01$; compared with PBO group, ${ }^{*} \mathrm{P}<0.05$; compared with LIRA group, ${ }^{\# \#} \mathrm{P}<0.01$; compared with LIRA group, " $\mathrm{P}<0.05$. LIRA, liraglutide treatment group. PBO, placebo group; CON, control group. FBG, fasting blood glucose; $2 \mathrm{hPG}, 2$ hours postprandial blood glucose; FINS, fasting serum insulin; PCD, positive cell density.
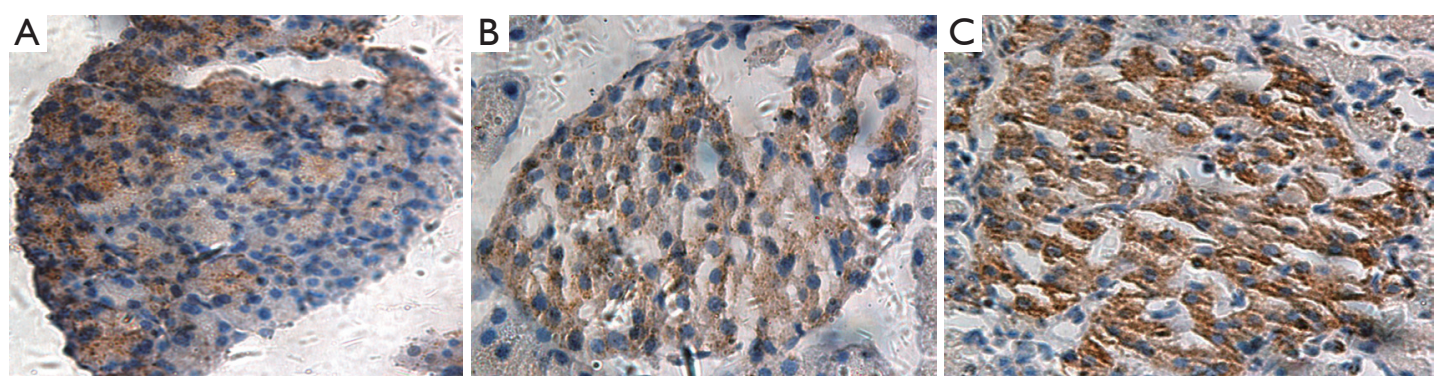

Figure 1 Insulin immunohistochemical staining of pancreas ( $\times 400)$. (A) Control group; (B) placebo group; (C) liraglutide treatment group.

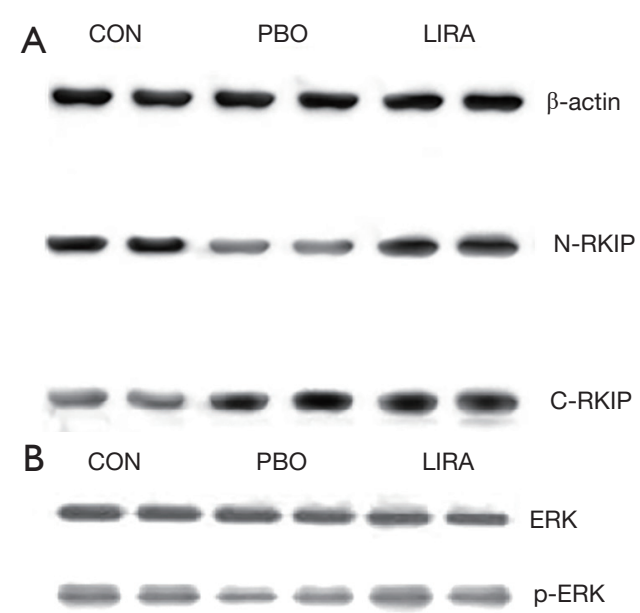

Figure 2 The expression of RKIP and p-ERK protein in rat pancreatic tissue. A, The expression of Raf-1 kinase inhibitor protein (RKIP) and B, GLP-1R relative to $\beta$-actin in pancreas. LIRA, liraglutide treatment group; CON, control group; $\mathrm{PBO}$, placebo group.

the $\mathrm{PBO}$ group, the relative content of p-ERK protein in the LIRA and CON groups was significantly increased, and the differences were statistically significant $(\mathrm{P}<0.05$, Figure 2 and Table 3).
Table 3 RKIP and p-ERK1/2 content relative to $\beta$-actin in the pancreas $($ mean $\pm \mathrm{SD})$

\begin{tabular}{lcccc}
\hline Groups & $\mathrm{n}$ & C-RKIP & $\mathrm{N}-\mathrm{RKIP}$ & $\mathrm{p}-\mathrm{ERK} 1 / 2$ \\
\hline CON & 6 & $0.66 \pm 0.08^{* *}$ & $0.63 \pm 0.07^{\star}$ & $0.84 \pm 0.12^{\star * \#}$ \\
LIRA & 6 & $0.72 \pm 0.03^{*}$ & $0.67 \pm 0.04^{*}$ & $0.73 \pm 0.05^{\star *}$ \\
PBO & 6 & $0.82 \pm 0.05$ & $0.59 \pm 0.11$ & $0.61 \pm 0.08$ \\
\hline
\end{tabular}

Compared with the PBO group, ${ }^{* *} \mathrm{P}<0.01$; compared with the PBO group, ${ }^{*} \mathrm{P}<0.05$; compared with the LIRA group, ${ }^{*} \mathrm{P}<0.05$. RKIP, Raf-1 kinase inhibitor protein; LIRA, liraglutide treatment group. PBO, placebo group; CON, control group; ERK, $\mathrm{p}$-extracellular signal-regulated kinase of phosphorylation.

ChAT and M3R gene expression in rat pancreatic tissue Compared with the PBO group, the ChAT mRNA and M3R mRNA expression levels in the CON group and the LIRA group were significantly higher, and the difference was statistically significant $(\mathrm{P}<0.05$, Table 4$)$.

\section{Discussion}

As an analog of human glucagon-like peptide-1 (GLP-1), liraglutide can prevent the degradation of dipeptidyl peptidase-4 (DPP-4) by increasing the fatty acid side chain and prolong its effect on pancreatic $\beta$-cells (12). A 
Table $4 C h A T$ and $M 3 R$ mRNA content in the pancreas (mean \pm SD)

\begin{tabular}{llcc}
\hline Groups & $\mathrm{n}$ & $C h A T\left(\times 10^{5}\right.$ copies $)$ & $M_{3} R\left(\times 10^{5}\right.$ copies $)$ \\
\hline CON & 6 & $3.68 \pm 0.72^{\star \star \# \#}$ & $21.73 \pm 3.16^{\star \star \#}$ \\
LIRA & 6 & $1.89 \pm 0.40^{\star \star}$ & $18.56 \pm 2.45^{\star \star}$ \\
PBO & 6 & $0.84 \pm 0.18$ & $11.22 \pm 1.82$ \\
\hline
\end{tabular}

Compared with the PBO group, ${ }^{* *} \mathrm{P}<0.001$; compared with the PBO group, ${ }^{*} \mathrm{P}<0.05$; compared with the LIRA group, ${ }^{\# \#} \mathrm{P}<0.01$; compared with the LIRA group, " $\mathrm{P}<0.05$. LIRA, liraglutide treatment group. $\mathrm{PBO}$, placebo group; CON, control group; ChAT, choline acetyltransferase; M3R, M3 cholinergic receptor.

number of studies have confirmed that liraglutide not only significantly improves $\beta$-cell function, but also increases the volume and number of $\beta$-cells $(5,13,14)$. This study demonstrated that liraglutide can improve the proliferation and insulin secretion of pancreatic $\beta$-cells and delay the occurrence of diabetes. The results of the study showed that IGT-OLETF rats without the intervention of liraglutide progressed to become diabetic, their C-RKIP protein levels increased, p-ERK protein levels decreased, and ChAT and M3R gene expression levels decreased significantly. This indicates that in IGT-OLETF rats, the effect of incretin stimulating hormone is decreased, the RKIP of pancreatic islet cells is increased, the blood sugar is increased, the proliferation of pancreatic $\beta$-cells is decreased, and the cholinergic neuroreceptor system is damaged, which in turn leads to increased blood sugar, insulin resistance and significant decline of the PCD of pancreatic islet cells. After 12 weeks of liraglutide intervention, OLETF rats showed not just significantly reduced food intake, body weight, and blood sugar, but also decreased C-RKIP protein levels, increased N-RKIP protein levels and p-ERK protein levels, and increased $C b A T$ and $M 3 R$ expression levels. Therefore, it is speculated that liraglutide can not only activate the ERK1/2 signal pathway and promote the proliferation of $\beta$-cells, but also promote the lysis of RKIP, leading to an increase in HCNP, further acting on the cholinergic nervous system and promoting the release of insulin.

RKIP can bind to Raf-1 and MEK-1, interfere with the phosphorylation and activation of MEK-1 by Raf-1, further inhibit the ERK1/2 signal pathway, and attenuate cell proliferation $(15,16)$. Zhang et al. showed that RKIP is specifically present in pancreatic islet cells using fluorescence double staining, immunohistochemical staining and other techniques, inhibiting the MAPK signal pathway and inhibiting the proliferation of pancreatic $\beta$-cells (9). A number of studies have demonstrated that RKIP plays an important role in the normal physiological processes in the body (17). Studies have shown that RKIP has a negative regulatory effect on glucose-induced cell viability, migration, angiogenesis, and endothelial-mesenchymal transition (EndMT) in human retinal capillary endothelial cells, suggesting that the downregulation of RKIP in the vitreous humor may contribute to the development of diabetic retinopathy in patients with proliferative diabetic retinopathy (18). Studies have also found that RKIP can inhibit the activation of NLRP1, NLRP3, and NLRC4, thereby playing a role in inflammasome-related diseases, including metabolic syndrome, gout, and atherosclerosis (19). Rituximab can regulate the expression of RKIP in the kidney tissue of diabetic nephropathy rats via nuclear factor kappa B (NF-kB) and can therefore aid in the treatment of diabetic nephropathy by regulating RKIP (20). The amino terminal of RKIP is cleaved by chymotrypsin-like enzymes into a polypeptide of 11 amino acid residues, namely HCNP, which can play a role in a variety of cells, including $\mathrm{T}$ cells, macrophages, and pancreatic $\beta$-cells $(21,22)$. Because the molecular weight of HCNP is small, western blotting technology cannot express its content, so after eluting the carboxy-terminal RKIP protein antibody on the nitrocellulose membrane with enhanced luminescence, the amino-terminal RKIP protein-specific antibody is readded to form the amino-terminal -RKIP (N-RKIP). The relative protein content of N-RKIP is used to indirectly determine the content of HCNP. Typically, the RKIP produced by cells is carbon-terminal-RKIP (C-RKIP). In experiments, we observed a decrease in C-RKIP and an increase in N-RKIP. Thus, it is speculated that liraglutide promotes RKIP cleavage, thereby increasing HCNP.

The concept of prediabetes was first proposed decades ago, but it has only recently become a focus of attention (23). In the United States, about one-fifth of adolescents and onequarter of young people have been diagnosed with diabetes. The prevalence of prediabetes is higher among male individuals and obese individuals (23). Abdominal obesity has been demonstrated to be closely related to prediabetes (24). A number of studies have shown that liraglutide has a significant effect on weight reduction in obese patients (25-27). This effect may be related to the delay of the gastric emptying of solid food by liraglutide (28). As a result of these findings, a large number of studies have observed the effect of liraglutide on the progression of prediabetes in obese patients. In their study, Kim et al. compared the effects of liraglutide versus a placebo on patients with prediabetes. The intervention group was given liraglutide $1.8 \mathrm{mg}$ for 
14 weeks. They found that the combination of liraglutide and calorie control can significantly reduce the weight of patients with prediabetes while improving insulin resistance and decreasing systolic blood pressure, as well. as glucose and triglyceride levels (29). In another study of intervention in obese patients, Astrup et al. found that $1.8-3 \mathrm{mg}$ of liraglutide per day can reduce prediabetes by $84-96 \%$ (30). According to existing research results, liraglutide can inhibit the progression of prediabetes in high-risk patients, and can also delay and reduce the progression of prediabetes to diabetes and cardiovascular and cerebrovascular diseases. However, the specific mechanism is still not clear. Our study provides a possible explanation: liraglutide promotes insulin secretion by increasing HCNP.

Our study is temporarily limited to the rat diabetes model, and the specific mechanisms of related signaling pathways need to be further studied. In addition, further research is needed to investigate whether liraglutide also affects the progression of prediabetes through other means and whether the drug can affect the cholinesterergic nerve activity of the gastrointestinal tract.

\section{Acknowledgments}

Funding: None.

\section{Footnote}

Reporting Checklist: The authors have completed the ARRIVE reporting checklist. Available at https://dx.doi. org/10.21037/atm-21-3094

Data Sharing Statement: Available at https://dx.doi. org/10.21037/atm-21-3094

Conflicts of Interest: All authors have completed the ICMJE uniform disclosure form (available at https://dx.doi. org/10.21037/atm-21-3094). Dr. HH is from Beijing Hengfeng Mingcheng Biotechnology Co., Ltd. This study had no fund or agents from this company. The other authors have no conflicts of interest to declare.

Ethical Statement: The authors are accountable for all aspects of the work in ensuring that questions related to the accuracy or integrity of any part of the work are appropriately investigated and resolved. Experiments were performed under a project license (No.: 2017-11-15) granted by ethics committee of Electric Power Teaching
Hospital, in compliance with national guideline for the care and use of animals.

Open Access Statement: This is an Open Access article distributed in accordance with the Creative Commons Attribution-NonCommercial-NoDerivs 4.0 International License (CC BY-NC-ND 4.0), which permits the noncommercial replication and distribution of the article with the strict proviso that no changes or edits are made and the original work is properly cited (including links to both the formal publication through the relevant DOI and the license). See: https://creativecommons.org/licenses/by-nc-nd/4.0/.

\section{References}

1. Tabak AG, Herder C, Rathmann W, et al. Prediabetes: a high-risk state for diabetes development. Lancet 2012;379:2279-90.

2. Wang L, Gao P, Zhang M, et al. Prevalence and Ethnic Pattern of Diabetes and Prediabetes in China in 2013. JAMA 2017;317:2515-23.

3. Carris NW, Magness RR, Labovitz AJ. Prevention of Diabetes Mellitus in Patients With Prediabetes. Am J Cardiol 2019;123:507-12.

4. Huang YQ, Liu L, Huang JY, et al. Prediabetes and risk for all-cause and cardiovascular mortality based on hypertension status. Ann Transl Med 2020;8:1580.

5. Santilli F, Simeone PG, Guagnano MT, et al. Effects of Liraglutide on Weight Loss, Fat Distribution, and betaCell Function in Obese Subjects With Prediabetes or Early Type 2 Diabetes. Diabetes Care 2017;40:1556-64.

6. le Roux CW, Astrup A, Fujioka K, et al. 3 years of liraglutide versus placebo for type 2 diabetes risk reduction and weight management in individuals with prediabetes: a randomised, double-blind trial. Lancet 2017;389:1399-409.

7. Panse M, Gerst F, Kaiser G, et al. Activation of extracellular signal-regulated protein kinases 1 and 2 (ERK1/2) by free fatty acid receptor 1 (FFAR1/GPR40) protects from palmitate-induced beta cell death, but plays no role in insulin secretion. Cell Physiol Biochem 2015;35:1537-45.

8. Morecroft I, Doyle B, Nilsen M, et al. Mice lacking the Raf-1 kinase inhibitor protein exhibit exaggerated hypoxia-induced pulmonary hypertension. Br J Pharmacol 2011;163:948-63.

9. Zhang L, Fu Z, Binkley C, et al. Raf kinase inhibitory protein inhibits beta-cell proliferation. Surgery 
2004;136:708-15.

10. Madokoro Y, Yoshino Y, Kato D, et al. Reduced Cholinergic Activity in the Hippocampus of Hippocampal Cholinergic Neurostimulating Peptide Precursor Protein Knockout Mice. Int J Mol Sci 2019;20:5367.

11. Zuo H, Liu X, Wang D, et al. RKIP-Mediated NF-kappaB Signaling is involved in ELF-MF-mediated improvement in AD rat. Int J Med Sci 2018;15:1658-66.

12. Tanday N, Flatt PR, Irwin N, et al. Liraglutide and sitagliptin counter beta- to alpha-cell transdifferentiation in diabetes. J Endocrinol 2020;245:53-64.

13. Ding M, Fang QH, Cui YT, et al. Liraglutide prevents beta-cell apoptosis via inactivation of NOX2 and its related signaling pathway. J Diabetes Complications 2019;33:267-77.

14. Anholm C, Kumarathurai P, Jurs A, et al. Liraglutide improves the beta-cell function without increasing insulin secretion during a mixed meal in patients, who exhibit well-controlled type 2 diabetes and coronary artery disease. Diabetol Metab Syndr 2019;11:42.

15. Man RJ, Zhang YL, Jiang AQ, et al. A patent review of RAF kinase inhibitors (2010-2018). Expert Opin Ther Pat 2019;29:675-88.

16. Wu PK, Becker A, Park JI. Growth Inhibitory Signaling of the Raf/MEK/ERK Pathway. Int J Mol Sci 2020;21:5436.

17. Keller ET, Fu Z, Brennan M. The role of Raf kinase inhibitor protein (RKIP) in health and disease. Biochem Pharmacol 2004;68:1049-53.

18. Feng L, Zhang C, Liu G, et al. RKIP negatively regulates the glucose induced angiogenesis and endothelialmesenchymal transition in retinal endothelial cells. Exp Eye Res 2019;189:107851.

19. Qin Q, Liu H, Shou J, et al. The inhibitor effect of RKIP on inflammasome activation and inflammasome-dependent diseases. Cell Mol Immunol 2021;18:992-1004.

20. Li L, Zhao YW, Zeng JS, et al. Rituximab regulates the expression of the Raf kinase inhibitor protein via NFkappaB in renal tissue of rats with diabetic nephropathy. Genet Mol Res 2013;12:2973-81.

21. Mashimo M, Murakami K, Inoue A, et al. Hippocampal Cholinergic Neurostimulating Peptide Suppresses LPS-

Cite this article as: Gao F, Wu D, Guo L, Wang L, Hao M, Li L, Ni D, Hao H. Liraglutide inhibits the progression of prediabetes in rats by reducing Raf-1 kinase inhibitor protein. Ann Transl Med 2021;9(14):1157. doi: 10.21037/atm-21-3094
Induced Expression of Inflammatory Enzymes in Human Macrophages. Biol Pharm Bull 2020;43:1430-3.

22. Saito Y, Mashimo M, Nobeyama A, et al. Hippocampal Cholinergic Neurostimulating Peptide Suppresses Acetylcholine Synthesis in T Lymphocytes. Biol Pharm Bull 2018;41:1611-4.

23. Andes LJ, Cheng YJ, Rolka DB, et al. Prevalence of Prediabetes Among Adolescents and Young Adults in the United States, 2005-2016. JAMA Pediatr 2020;174:e194498.

24. Sangros FJ, Torrecilla J, Giraldez-Garcia C, et al. Association of General and Abdominal Obesity With Hypertension, Dyslipidemia and Prediabetes in the PREDAPS Study. Rev Esp Cardiol (Engl Ed) 2018;71:170-7.

25. Davies MJ, Bergenstal R, Bode B, et al. Efficacy of Liraglutide for Weight Loss Among Patients With Type 2 Diabetes: The SCALE Diabetes Randomized Clinical Trial. JAMA 2015;314:687-99.

26. Khera R, Murad MH, Chandar AK, et al. Association of Pharmacological Treatments for Obesity With Weight Loss and Adverse Events: A Systematic Review and Metaanalysis. JAMA 2016;315:2424-34.

27. Pi-Sunyer X, Astrup A, Fujioka K, et al. A Randomized, Controlled Trial of $3.0 \mathrm{mg}$ of Liraglutide in Weight Management. N Engl J Med 2015;373:11-22.

28. Halawi H, Khemani D, Eckert D, et al. Effects of liraglutide on weight, satiation, and gastric functions in obesity: a randomised, placebo-controlled pilot trial. Lancet Gastroenterol Hepatol 2017;2:890-9.

29. Kim SH, Abbasi F, Lamendola C, et al. Benefits of liraglutide treatment in overweight and obese older individuals with prediabetes. Diabetes Care 2013;36:3276-82.

30. Astrup A, Rossner S, Van Gaal L, et al. Effects of liraglutide in the treatment of obesity: a randomised, double-blind, placebo-controlled study. Lancet 2009;374:1606-16.

(English Language Editors: G. Stone and J. Gray) 